\title{
Economic Growth in ASEAN-4 Countries: A Panel Data Analysis
}

\author{
Fauzi Hussin ${ }^{1} \&$ Nooraini Saidin ${ }^{1}$ \\ ${ }^{1}$ School of Economics, Finance and Banking, College of Business, Universiti Utara Malaysia, Malaysia \\ Correspondence: Fauzi Hussin, School of Economics, Finance and Banking, College of Business, Universiti \\ Utara Malaysia, 06010 Sintok, Kedah, Malaysia. Tel: 60-4-928-3549. E-mail: fauzi@uum.edu.my
}

Received: April 17, 2012

doi:10.5539/ijef.v4n9p119
Accepted: July 16, $2012 \quad$ Online Published: July 30, 2012

URL: http://dx.doi.org/10.5539/ijef.v4n9p119

\begin{abstract}
This paper examines the impact of economic variables which are foreign direct investment (FDI), openness and gross fixed capital formation to economic growth which indicates using gross domestic product (GDP) over the period 1981-2008. The impact of variables to GDP is estimated using three panel estimation models which are called pooled model (pooled), fixed effects model (FEM) and random effects model (REM). The findings show that all variables are correlated with each other and also have the positive relationship to GDP. Hence, all variables may lead economic growth boost when they are increase whereas FDI becomes the most efficient variable in order to assist economic growth and followed by openness and gross fixed capital formation. Otherwise, the result in Ordinary Least Squares (OLS) which implies in this study as well test all variables stationary at 5 percent level of significant. These shows only gross fixed capital formation is significant to growth and contributes the positive effect to GDP in each ASEAN-4 countries. However, OLS estimation result for Indonesia shows the other variable has significant to growth which is openness; while it gives the negative affect the GDP. Instead of Indonesia, openness is not significant at other ASEAN-4 countries such as Malaysia, Thailand and Philippines. Besides, other variable is FDI also not significant in the case of all ASEAN-4 countries. It means that, openness does not correlated to growth for Malaysia, Thailand and Philippines countries; while FDI is not correlated to growth for all ASEAN-4 countries in this study.
\end{abstract}

Keywords: FDI, openness, Gross Fixed Capital Formation, economic growth, ASEAN-4

\section{Introduction}

Economic growth is the expansion in a nation's economy which can be measured using several approaches, most often used is Gross Domestic Product (GDP). Chaudhuri (1989) noted that economic growth refers to the quantitative dimension in national income, output per capita or real total output over time in which national income is best approximated by GDP and per capita income (Hassan, 2004). Other researchers provide several other definitions for economic growth. For instance, Peterson (1978) defined economic growth as the expansion of a nation's capability to produce the goods and services its people want. He further explained that economic growth involves an increase over time in the actual output of goods and services as well as an increase in the economy's capability to produce goods and services. Meanwhile, Fuller (1991) defined economic growth as an increase in the productive capacity of an economy relating to the growth in GDP. According to this definition, GDP is the performance in terms of a nation production. In other words, economic growth can be defined as the expansion of goods and services in a country which can lead to higher consumption. This situation may lead to increase in labor demand followed by a high income of labor. High income of labor subsequently implies an increase in GDP which is defined as economic growth earlier.

\section{Overview of 4 Economies}

Investment in the manufacturing sector is one of the main factors that contribute to Malaysia's growth. Shifting its focus from the agriculture sector to manufacturing combined with rapid increase in manufacturing contribute to economic growth. The manufacturing sector later evolves from a labor intensive industry to a capital intensive and high technology industry. Meanwhile, the agriculture sector showed a continuous decline in average growth, 5.7 per cent for the period $1971-1975$ to 3.2 per cent for 1981 - 1985. Average growth declined further to 1.5 per cent from 2001 - 2003 (Chamhuri, Surtahman, \& Norshamliza, 2005). Several other policies also play significant role in influencing Malaysia's economic performance. For instance, four decades ago, the government introduced Malaysia's New Economic Policy (NEP) with the objective to alleviate poverty. This policy marks the 
ending of classification of economic functions by ethnic group. It was later replaced by the National Development Policy (NDP) in 1991. In addition, a new programme called the Economic Transformation Programme (ETP) under Government Malaysian Performance Management and Delivery Unit (PEMANDU) was introduced with the aim to become a high income country in the future.

Indonesia is Malaysia's neighboring country, comprising of several islands, with Jakarta as its center of administrative function. Gray (2002) presents the economic history for seven decades earlier for Indonesia. The economic policy during the Sukarno presidency until 1965 was focus more on fiscal stimulus by money creation. This led to high inflation and stagnation in the economy. Food shortage contributed to high inflation and unemployment rate was high in 1965. After President Suharto's takeover of the administration, there was a change in government policies. Fiscal and monetary policies were still important and oil became the important resource in the economy. These policies proved to be very successful. The average growth rate was 8 per cent during the 1970s period. However, in the early 1980s, bureaucracy slowed down growth. The collapse in the oil sector in 1986 subsequently had great effect on government policies. Next, investment from the private sector became an important factor which boosts the GDP growth rate during the 1986 to 1997 period. The economy became a more open market economy. Foreign Direct Investment (FDI) became an important contributor to Indonesia's economy. This period showed high rates of growth in the economy. However, the Asian economic crisis 1997-1998 caused Indonesia to experience slower growth. In 1998, Indonesia's real GDP had declined to 13 per cent (Gray, 2002).

Thailand is also a Southeast Asian country located near Cambodia and Laos. Before the Asian Financial Crisis, the growth in the manufacturing sector in a decade until 1996 was around 9.4 per cent. This remarkable growth was made possible by factors such as abundant natural resources, number of labor, prudent fiscal policy and open policy with regards to foreign investment. More than 60 per cent of total labor is involved in the agriculture sector. Paddy cultivation is the main agricultural activity for Thailand, which is an important exporter of rice in the world. GDP in 2009 decreased to Baht 9,041,550 million from Baht 9,075,490 million for the previous year, while for the other years, the amount increases annually. FDI in 2008 and 2009 declined from the previous years. In 2008, FDI totaled Baht 281,434.3 million, declining from Baht 391,955.3 million in 2007. This figure further declined in 2009 to Baht 170,603.7 million. Trade balance for Thailand in 2008 experienced the most severe downturn at -US2, 783 million. From 2009 to 2010, it fell from US17, 159 million to US10, 785 million.

For the Philippines, Cebu, Davao-General Cantos and Subic-Clark are the regional centers that had faster development growth. This is due to expansion in exports and total investment compared to other area such as Metro Manila. The Philippines is a country which has a high rate of urbanization in the 20th century (Pernia \& Quising, 2003). The economic structure of the Philippines is focus on the industrial sector such as textile, electronic and food processing. The industrial areas are located in the Manila area. The economy is also highly dependent on agriculture and mining. Its natural resources consist of chromites, copper and nickel. Philippines had recorded a strong economic performance in 2005 with GDP growth at 5.1 per cent. Public sector deficits and debts had also reduced. This was the second time that the Philippines had a growth rate above 5 per cent. The first was in 2004 when the GDP growth was 6 per cent. Income per capita for 2005 had also increased by 2.9 per cent (World Bank, 2011). GDP for the Philippines keep increasing every year from Ps6, 271,160 in 2006 to Ps9, 003,480 million in 2010. FDI experienced a decline from 2006 until 2008, it went up in 2009 to Ps93, 595.3 million from Ps68, 435.2 million in the previous year. Trade balance recorded negative amounts from 2006 until 2010. However, the negative balance gradually reduces in 2009 and 2010 at - US7, 426.9 million and -US6, 796.8 million, respectively.

\section{Literature Review}

According to Gray (2002), FDI is defined as a source of technologies and skills valuable in the long term. FDI is one of the important factors in economic development process. After the financial crisis, FDI became an important factor contributing to Indonesia's growth. Gray examined FDI and how FDI inflows recovered in Indonesia. Development projects in Indonesia hold uncertainty for investors. Factors such as restrictions in the projects, high taxes and charges are some of the issues of FDI in Indonesia. Furthermore, there are also problems between the national and local governments in Indonesia. The impact of FDI in Indonesia can be seen through three agencies namely Semen Gresik, Caltex and Kaltim Prima Coal (KPC).

Theoretical framework of the endogeneity of financial openness and trade openness is the objective of research by Aizenman and Noy (2009). Their study examines two-way causality between trade openness and financial openness in developing countries. By letting FDI fragment the optimal productivity, countries may get the benefits from cost advantage associated with labour intensive production stage in the abundant labour country. 
Their model is characterized by political uncertainty and limited tax. Fiscal tools ware financed by implicit tax and direct income tax. Using Geweke's causality technique, the findings revealed that an increase of 1 per cent in trade openness leads to an increase of 9.5 per cent in the international financial flows in the domestic country. There exists a bi-directional causality where financial openness leads to an expansion in trade openness. However, there was still a restriction in the current accounts that will have a negative effect on trade openness in the developing countries.

Inward FDI and economic growth have a bi-directional causal link in Portugal. This finding is based on a research by Andraz and Rodrigues (2009). Their study uses a three-stage technique while the data are from 1977 to 2004. The purpose was to investigate Granger-causality between growth, FDI and export. FDI was significant in short run and FDI also Granger-caused total real exports. The finding shows that FDI is one of the indicators that influence GDP growth in Portugal. However, export does not affect GDP growth rates. Expansion in FDI affects total capital formation in the economy. Subsequently, the increase in total production capacity and external competitiveness will increase growth rates.

Mandilaras and Popper (2009) investigate international capital flows in seven East Asian countries. The purpose was to determine the indicators of net outflows. The study also evaluates the effect of openness in financial markets on international capital flows, including the link between domestic capital flows and international capital flows in the East Asian countries. The findings show that domestic capital markets is a good indicator in explaining the changes in total capital flows in the seven East Asian countries. Furthermore, openness in capital markets is also important in influencing total capital flows in the economy. The US macroeconomic variables are significant in determining the growth of GDP. Adhikary (2011) reports that based on theoretical linkage, the relationship between economic growth, trade openness, foreign direct investment (FDI) and capital formation tends to be positive.

Causality between trade openness and per capita real GDP and the impact of openness in eight Union Economique et Monetaire Ouest-Aafricaine (UEMOA) countries were investigated by Agbetsiafa (2010). The study uses three measurement of trade openness. By using the Johansen cointegration test, trade openness and growth rate are shown to have a long run equilibrium relationship. There exist bidirectional causality between total trade and per capita real GDP in Ivory Coast, Niger and Burkina Faso. However, in Benin, Mali, Guinea Bissau, Togo and Senegal, causality is unidirectional. The researcher also suggests increasing exports in intermediate goods, improving facilities and human capital in order to increase per capita real GDP, and avoiding deficits in the country. Asid (2010) uses real GDP of workers as a proxy for economic growth. Human capital and FDI are the independent variables that have significant effect on growth. Meanwhile openness is weakly significant in a certain model of growth. Grossman and Helpman (1991) \& Romer (1992) (as cited in Asid, 2010) also support this findings because economic openness will increase the opportunity for the domestic country to absorb technologies from foreign countries.

Chimobi (2010) analyzed the relationship and causality between economic growth and trade openness and financial development in Nigeria. The financial variable is separated into three sub-variables which are private credit, money supply and direct credit. The time series data are from 1970 to 2005. First, testing for stationary using the Augmented Dickey Fuller (ADF) test, the result shows that all the variables are stationary at first difference. However, the long run relationship shows that all the independent variables are not co-integrated. The Granger causality test also shows that the two independent variables do not have causal effect on growth. On the other hand, growth affects financial development and trade openness in Nigeria. Money supply is the only financial development variable seen to have an effect on the level of trade openness in the country. Hoang, Wiboonchutikula, and Tubtimtong (2010) examine the impact of FDI on growth rates in Vietnam. They use panel data over a period of 1995 to 2006. The finding shows that FDI had a significant effect on growth rates in Vietnam. The increase of 1 per cent in FDI will expand economic growth to 0.012 per cent. Further, the study also examines whether human capital has significant effect on growth. Gregorio, Borenstzein, \& Lee (as cited in Hoang et al. (2010)) suggest that FDI only has a positive effect when the stock of human capital reached a certain threshold. Only at this threshold can a country exploit the technology absorbed from FDI. The determinants of FDI in Canada had been examined by Leitao (2010). The study examines the determinants of FDI in Brazil, Japan and the EU-15. Using GMM system estimator and Fixed Effects estimators, the findings show that trade openness and market size were the significant factors that influence the total inflows of FDI in Canada. North American Free Trade Agreement (NAFTA) and Free Trade Agreements (FTA) are the policies that attracted inward FDI to Canada. Tax and wages also had significant influences in determining total FDI in Canada. The stability of macroeconomic policies attracts foreign investors to invest in the country. 


\section{Sources and Definition of the Variables}

\subsection{Source of Data}

This study is an empirical study using secondary data. Annual data from 1981 to 2008 of four ASEAN countries namely Malaysia, Indonesia, Thailand and Philippines were collected from World Development Indicator (WDI) published by the World Bank. Data for total GDP, FDI, export, import and gross fixed capital formation for 1981 to 2005 were obtained from the World Development Indicator (WDI) 2007 CD-ROM. For years 2006 to 2008, data were extracted from the World Development Indicator (WDI) website.

\subsection{Definition of Variables}

The dependent variable in this study is GDP. It has been shown that GDP can describe the economic growth in the ASEAN-4 countries. The explanatory variables consist of three independent variables namely FDI, trade openness and gross fixed capital formation. All the dependent and independent variables are stated in constant price (2000 - 100) to ensure that there are no inflation effects.

\subsubsection{Gross Domestic Product (GDP)}

Gross Domestic Product (GDP) is a measure of aggregate output produced in an economy. This particular output can be classified into 3 categories: the total value of output produced, the total value of incomes yielded in producing the output, or the total expenditures on the output (Artis, 1984). Economic growth is defined as the growth rate of GDP for each ASEAN-4 country. The GDP growth rate is derived by taking difference between the current year GDP and the previous year GDP divided by the previous year GDP and multiplied by hundred.

As an example, the economic growth in 2010 can be seen by comparing the growth rate of GDP in 2010 can be seen by comparing the growth rate of GDP in 2010 with the growth rate of GDP in 2009. Thus, while the growth rate of GDP for 2010 is larger than the growth rate of GDP 2009, it means that there has an economic growth in 2010 and vice versa. The growth rate of GDP can be obtained as follows:

$$
\text { Growth rate of GDP }=\text { [GDP (2010) }- \text { GDP (2009)] / GDP (2009) x } 100
$$

An increase in $n$ in economic growth will help a country to increase its per capita income. In addition, economic growth will increase demand for labour, subsequently decreasing the unemployment rate. Economic growth also helps a country reduce its poverty rate and also achieve a higher standard of living for its citizens.

GDP is used as the dependent variable in this study since it can represent economic growth for a country. Meanwhile, the independent variable such as FDI, openness and gross fixed capital formation are the determinants of GDP since they can influence economic growth.

\subsubsection{Foreign Direct Investment (FDI)}

Foreign Direct Investment (FDI) or Foreign Investment is defined as the net inflows of investment to achieve a lasting management interest in a business operating in an economy other than that of the investor. FDI is the sum of equity capital, other long-term capital and short-term capital as shown in the balance of payments, and reinvestment of earnings. FDI is divided into two types: inward foreign direct investment and outward foreign direct investment. Both types will result in a net FDI inflow that can be positive or negative in values. The formula to find FDI net inflow is:

$$
\text { FDI net inflow }=\text { FDI inflow }- \text { FDI outflow }
$$

Inflow of FDI results in an additional increase in the transfer of skills, technologies and job opportunities for a country. ASEAN countries such as the Philippines and Singapore obtain significant benefits from FDI. For that reason, this study examines the importance of FDI in increasing the economic growth.

\subsubsection{Openness}

Openness is defined as an economy which trades with the rest of the world. In other words, there exist economic activities such as import and export for a country. Countries like the ASEAN members who practice foreign trade are known open economies. Openness can be measured as follows:

$$
\text { Openness }=(\text { total export }+ \text { total import }) / \text { total GDP }
$$

Economic openness brings many advantages such as consumers have plenty of choices since there are variety of goods and services in the economy. Moreover, the country's citizens have the opportunity to invest their savings abroad. Furthermore, open economy appears to be beneficial for regional development, at the same time indirectly reducing poverty among citizens, (Pernia and Quising, 2003). 


\subsubsection{Gross Fixed Capital Formation}

European System of Accounts (ESA) defines gross fixed capital formation as resident producers' acquisitions of fixed assets during a given period, less disposals, plus certain additions to the value of non-produced assets that are realized by the productive activity of producer or institution. The importance of gross fixed capital formation is in quantifying the value of the acquisitions less disposals of fixed assets which is future replacement for obsolescence of existing assets because of normal wear.

Uremadu (2006) defines gross fixed capital formation as an addition in stock of capital assets set. It is a part of the stock of capital assets set that is used for future productive endeavours in the real sector. It will conduct to increase physical capital assets of a country. It gains from savings accumulation which gives positive effect to private savings accumulation, in other word contributes more savings. Increase in savings accumulation leads to increase in gross domestic investment (GDI), next more investment projects will made. Investment projects will generate income and this will increase GDP growth (Anthony and Peter, 2011).

From the above discussion, it is clear that gross fixed capital formation is not a measure of total investment since only the value of net additions to fixed assets is counted and all kinds of financial assets like other operating costs and stocks of inventories are excluded. As an example, it is easy to find fixed assets when we examine a company's balance sheet. This is because fixed assets are the only component of the total annual capital outlay.

\section{Methodology}

\subsection{Model Specification}

The model can be described as follows:

$$
\begin{gathered}
g d p=f(f d i, \text { open, capfor }) \\
g d p_{i t}=\beta_{0}+\beta_{1}\left(\text { fdit }_{i t}\right)+\beta_{2}\left(\text { open }_{i t}\right)+\beta_{3}\left(\text { capfor }_{i t}\right)+\mu_{i t}
\end{gathered}
$$

Where:

$$
\begin{aligned}
& \text { gdp : Growth Domestic Product (GDP) } \\
& \text { fdi : Foreign Direct Investment (FDI) } \\
& \text { open: Openness } \\
& \text { capfor } \quad: \text { Gross Fixed Capital Formation } \\
& \mu \quad: \text { error term } \\
& 5.2 \text { Estimation Procedure }
\end{aligned}
$$

This section explains the econometric procedure in testing time series data and panel data which are used in the study. The most appropriate estimation procedure to be used based on various conditions are discussed in order to achieve the objective of the study. The possibility of panel cointegration will be examined using the panel unit root test. Panel unit root test is used to test whether the data is stationary or non-stationary. Im, Pesaran and Shin (2003) (IPS) explain that the Dickey-Fuller (DF) unit root test which applies in panel is used to allow for heterogeneous deterministic intercept terms (Harris, Harvey, Leybourne and Sakkas, 2008). In the case of the limiting fraction of a stationary series is non-zero as $N \rightarrow \infty$ the $L M$-bar test is consistent as proposed by IPS (Harris et al. ,2008). In addition, (IPS, 2003) denoted a general setting in a standardized $t$-bar test statistic where the DF statistics is depicted to converge in probability to a standard normal variate consecutively with $T \rightarrow \infty$ for time series dimension and $N \rightarrow \infty$ for cross section dimension. Panel unit root test involves two types, at level and first difference. By using panel unit root test, the data can be ensured to be stationary in level or first difference.

The IPS model for this study is shown as follows:

Model 1: Malaysia

$$
\begin{gathered}
g d p_{\text {mal }}=f(f d i, \text { open, capfor }) \\
g d p_{i t}=\beta_{0}+\beta_{1}\left(\text { fdi }_{i t}\right)+\beta_{2}\left(\text { open }_{i t}\right)+\beta_{3}\left(\text { capfor }_{i t}\right)+\mu_{i t}
\end{gathered}
$$

Model 2: Indonesia

$$
\begin{gathered}
g d p_{\text {ind }}=f(f d i, \text { open, capfor }) \\
g d p_{i t}=\beta_{0}+\beta_{1}\left(f d i_{i t}\right)+\beta_{2}\left(\text { open }_{i t}\right)+\beta_{3}\left(\text { capfor }_{i t}\right)+\mu_{i t}
\end{gathered}
$$

Model 3: Thailand 
Model 4: Philippines

$$
\begin{gathered}
g d p_{t h a}=f(f d i, \text { open, capfor }) \\
g d p_{i t}=\beta_{0}+\beta_{1}\left(f d i_{i t}\right)+\beta_{2}\left(\text { open }_{i t}\right)+\beta_{3}\left(\text { capfor }_{i t}\right)+\mu_{i t}
\end{gathered}
$$

$$
\begin{gathered}
g d p_{p h i}=f(f d i, \text { open, capfor }) \\
g d p_{i t}=\beta_{0}+\beta_{1}\left(\text { fdi }_{i t}\right)+\beta_{2}\left(\text { open }_{i t}\right)+\beta_{3}\left(\text { capfor }_{i t}\right)+\mu_{i t}
\end{gathered}
$$

Panel data are sets of data on the same individual over respective periods of time (Maddala (1994). However, data sets are sometimes incomplete. In other words, there are missing data for a certain period of time. In addition, data sets are sometimes available for a short of period of time such as two to seven years. This kind of data sets is denoted as 'short panels' (Maddala, 1987). Panel data is used in empirical analysis where two types of data, cross-sectional and time series data are combined. Baltagi (1995) discusses that there are three advantages of panel data. First, estimator technique of data panel heterogeneity is explicit for every micro unit. Second, such combination of data gives much more information, which means it more quality as a variable and there are less colinearity problem among the variables. Third, panel data provide advantage in studying complex behaviour. In addition, Hsiao (1985, 1986), Klevmarken (1989) and Solon (1989) (cited in Baltagi, 1995) suggest that the use of panel data is advantageous in studying the dynamics of adjustment. It is also well suited in studying economic duration, useful in order to adjust to economic policy changes. Panel data are also simple in identifying and measuring effects instead of pure time series data or pure cross-sections data.

In Maddala (1994), several arguments are put forward with regard to using random effects models rather than fixed effects models. If the of number of cross-section units are large compared to estimating $\mathrm{N}$ of the $\alpha_{\mathrm{i}}$, only the mean and variance will be estimated in the random effects models. Hence, a lot of degrees of freedom will be saved. Maddala (1971) says that we ignore $\mu_{\mathrm{it}}$ measure effects for the $i$-th cross section unit in the $t$-th period as somehow we ignore $\alpha_{\mathrm{i}}$ measure firm specific effects. Therefore, if we addressed $\mu_{\mathrm{it}}$ as a random variable, there is no reason that $\alpha_{\mathrm{i}}$ should be otherwise (Maddala, 1994). In addition, if the inferences to be made are only about a set of cross-section units, $\alpha_{\mathrm{i}}$ should be treated as fixed. In contrast, if the inferences to be made are about the population from which these cross-section data came from, $\alpha_{i}$ should be treated as random. Some time-invariant variables like years of schooling and family background in studies of wages (Lillard and Willis, 1978) are used as examples as shown in this model:

$$
y_{i t}=\gamma^{\prime} z_{i}+\beta^{\prime} x_{i t}+\alpha_{i}+\mu_{i t}
$$

Based on this case, one model has been employed called the random effects model. If the fixed effects model were used, the parameters $\gamma$ cannot be estimated. This is because $\alpha_{i}$ captures the effect of all the time-invariant variables (Maddala, 1994).

In choosing the most suitable model, it should depend on the statistical properties of the implied estimator. Neyman and Scott from the classical problem of incidental parameters in Chamberlain, 1980; the fixed effects model results in inconsistent parameters in dynamic models applying small values of $T$ and large values of $N$ (Maddala, 1994). On the contrary, Mundlak (1978) argues that the duality of fixed effects and random effects models will disappear if the assumption of $\alpha_{i}$ depends on the mean value of $x_{i t}$. This assumption is sensible in many problems. As an example:

$$
\alpha_{i}=\pi^{\prime} \bar{x}_{i}+w_{i}
$$

Hoch $(1962)$ and Mundlak $(1961,1963)$ allowed for unobserved effects specific to each production unit in the early stage of using panel data. The model given is referred to as the fixed effects model:

$$
\begin{gathered}
y_{i t}=\alpha_{i}+\beta^{\prime} x_{i t}+\mu_{i t} \\
t=1,2 \ldots T
\end{gathered} \quad i=1,2 \ldots N
$$

Substituting (1) in (2.1), produces:

$$
y_{i t}=\pi^{\prime} \bar{x}_{i}+\beta^{\prime} x_{i t}+w_{i}+\mu_{i t}
$$

By using the ordinary least squares for the equation noted by Fuller and Battese (1973) argument, the estimator $\beta$ from the random effects model can be obtained.

$$
y_{i t}-\lambda \bar{y}_{i}=\pi^{\prime}\left(\bar{x}_{i}-\lambda \bar{x}_{i}\right)+\beta^{\prime}\left(x_{i t}-\lambda \bar{x}_{i}\right)+v_{i t}
$$




$$
=\beta^{\prime}\left(x_{i t}-\bar{x}_{i}\right)+\delta^{\prime} \bar{x}_{i}+v_{i t}
$$

Where: $\delta=(\pi+\beta)(1-\lambda)$ and $\lambda=1-\sqrt{\theta}$

As $\bar{x}_{i}$ is orthogonal to $x_{i t}-\bar{x}_{i}$. Also as $\operatorname{Cov}\left[\left(x_{i t}-\bar{x}_{i}\right)\left(y_{i t}-\lambda \bar{y}_{i}\right)\right]=W_{x y}$ the result produces $\hat{\beta}=W_{x x}^{-1} W_{x y}$ as the within group estimator. The random effects model gives the same estimator as the fixed effects model for this particular case.

$$
\hat{\delta}=\left(\Sigma \bar{x}_{i} \bar{x}_{i}^{\prime}\right)-1\left(\Sigma \bar{y}_{i} \bar{x}_{i}(1-\lambda)\right)
$$

Will produce:

$$
\hat{\pi}=\hat{\delta}=\left(\sum \bar{x}_{i} \bar{x}_{i}^{\prime}\right)-1\left(\sum \bar{x}_{i} \bar{y}_{i}\right)-\hat{\beta}
$$

Mundlak arguments are true in the case of all the elements in $\pi$ are nonzero. Based on the earlier discussion in (2.1), the argument is reasonable and we will get:

$$
\alpha_{i}=\pi^{\prime} \bar{x}_{i}+\gamma^{\prime} z_{i}+w_{i}
$$

due to this case, (2.1) will become

$$
y_{i t}-\lambda \bar{y}_{i}=\beta^{\prime}\left(x_{i t}-\bar{x}_{i}\right)+\delta^{\prime} \bar{x}_{i}+(1-\lambda) \gamma^{\prime} z_{i}+v_{i}
$$

since $\left(\frac{1}{T}\right) \Sigma_{t}\left(x_{i t}-\bar{x}_{i}\right) z_{i}=0$; again the estimator of $\beta=W_{x x}^{-1} W_{x y}$ as the within group estimator will be obtained.

On the other hand, if not all of the elements in $\pi$ are nonzero, clearly the argument is no longer reasonable. Let say we separate the variables $x_{i t}$ into two sets $x_{1 i t}$ and $x_{2 i t}$. Similar to $x_{i t}, \beta$ is also separated into $\beta_{1}$ and $\beta_{2}$. Suppose (4) is changed to:

$$
\alpha_{i}=\pi_{1}^{\prime} \bar{x}_{1 i}+\gamma^{\prime} z_{i}+w_{i}
$$

corresponding to (6)

$$
y_{i t}-\lambda \bar{y}_{i}=\beta_{1}^{\prime}\left(x_{1 i t}-\bar{x}_{1 i}\right)+\beta_{2}^{\prime}\left(x_{2 i t}-\lambda \bar{x}_{2 i}\right)+\delta_{1}^{\prime} \bar{x}_{1 i}+(1-\lambda) \delta^{\prime} z_{i}+v_{i t}
$$

Where $\delta_{1}=\left(\pi_{1}+\beta_{1}\right)(1-\lambda)$. In this case the least square estimation does not produce the within group estimator even for the subvector $\beta_{1}$. Exception is for the case of the variables $x_{1}$ and $x_{2}$ are orthogonal.

\section{Results}

Panel unit root test is used to test stationary with various degree of heterogeneity. Karlsson and Lothgren (2000) point out that the power of panel unit root test increase when there is an increase in the number of panel series. In addition, the null hypothesis in this panel test has a unit root for each series and hence it is difference stationary. This method is used to test the stationary of the four variables in the four ASEAN countries. The result shows that all variables included in the study do have unit roots at level which means it is not stationary. However, only one variable which is GDP for the Philippines and Malaysia do not have unit root and stationary in level. Hence, unit root test for the variables at first difference are carried out to determine whether the series are stationary at first difference. The results of unit root test at first difference indicate that all variables are stationary at first difference. Thus the null hypothesis can be rejected and all variables in ASEAN-4 countries do not have unit root and stationary at first difference.

The result of pooled estimation for the four countries in Table 1 shows that FDI has the largest effect on GDP compared to the other independent variables. We arrive at this conclusion by comparing the coefficient values of the three variables. FDI shows the highest coefficient value (5.67) compared to openness (2.47) and gross fixed capital formation (2.21). However, openness and gross fixed capital formation also affect economic growth. Furthermore, the value of R-square is 0.87 , which explains that the relationship between the dependent variable (GDP) and all the independent variables (FDI, open, capfor) is high. The value means that about 87 percent of 
variation that occurs in GDP can be explained by FDI, openness and gross fixed capital formation. Fixed effects model is used to identify the different impact of the independent variables on the dependent variable. In our case, the fixed effects model is used to determine whether FDI, openness and gross fixed capital formation have different impact on GDP. The fourth column presents the results of pooled estimation based on random effects model. The coefficient value of FDI is 3.38 , which shows that there is a positive relationship between the dependent variable (GDP) and the independent variable (FDI). On the other hand, the coefficient value for openness is -1.35 shows that there is a negative relationship between openness and GDP. Meanwhile, the coefficient value for gross fixed capital formation is 2.79 indicates that is a positive relationship between this variable and GDP.

Table 1. Pooled Estimation Results for Three Independent Variables in ASEAN-4 Countries

\begin{tabular}{lccc}
\hline & Pooled Model & Fixed Effects Model & Random Effects Model \\
\hline Constant & $3.42^{* *}$ & 5.23 & $3.38^{* *}$ \\
& $(4.56)$ & $(0.78)$ & $(6.27)$ \\
\hline \multirow{2}{*}{ Fdi } & $1.52^{* *}$ & $5.67 * *$ & $5.20^{* *}$ \\
& $(2.91)$ & $(4.08)$ & $(3.76)$ \\
\hline \multirow{2}{*}{ Open } & $-1.32^{* *}$ & $2.47 * *$ & $-1.35^{* *}$ \\
& $(-2.24)$ & $(3.27)$ & $(-3.09)$ \\
\hline Capfor & $2.77^{* *}$ & $2.21^{* *}$ & $2.79^{* *}$ \\
& $(12.85)$ & $(10.02)$ & $(17.88)$ \\
\hline $\mathrm{R}^{2}$ & 0.74 & 0.87 & 0.73 \\
\hline Hausman Test & & $p=0.00$ & \\
\hline
\end{tabular}

Note: ** indicates the rejection of null hypothesis of non-stationary at 5\% significant level. ( ) indicates the t-statistic value

Table 2 shows the OLS estimation for the ASEAN-4 countries to determine the relationship between the dependent variable (GDP) and the independent variables, which is FDI, openness and gross fixed capital formation. The result shows that there are only one variable, which is gross fixed capital formation has positive correlation and significant for all countries. FDI and openness has positive relationship but not significant for Malaysia and Thailand. For Indonesia, there are two variables, namely openness and gross fixed capital formation significant at first difference. FDI is not significant at first difference which indicates that it has no correlation with GDP in this country. However, openness shows a negative correlation with GDP. In Thailand, FDI and openness are not significant at first difference. This means that there are no correlation between FDI and openness with GDP. The results of the OLS estimation for the Philippines demonstrate that only gross fixed capital formation is significant at first difference. Therefore, gross fixed capital formation is identified as having a correlation with GDP and the correlation is positive.

From the OLS estimation for Malaysia, Indonesia, Thailand and Philippine, the results indicate that economic growth in the ASEAN-4 countries are determined by gross fixed capital formation. This situation is similar to the study by Hu and Khan (1997) about why China grows so fast. Their study found that capital formation is the major factor in influencing economic growth. Other variables do not appear to affect growth. However, in Indonesia, openness gives a negative impact to growth. Asid's (2010) study on economic growth analyses under the TRIPS transitions says that evidence from selected cross-country samples found that openness is weakly significant in certain models of economic growth. In other words, openness is also related to other factors that affect growth. In the case of Indonesia, in terms of geography, country is frequently exposed to natural disasters. Therefore, this factor also affects the attraction of international trade in the country. Consequently, this factor can distort the effect of openness; Weil (2005) found that openness relates to efficiency in an economy where economic efficiency may help in maximizing production. 
Table 2. OLS Estimation for ASEAN-4 Countries

\begin{tabular}{llll}
\hline Country & Variables & Coefficient & T-statistic \\
\hline Malaysia & Fdi & 0.28 & 0.68 \\
& Open & 2.40 & 0.05 \\
& Capfor & 0.67 & $4.71^{* *}$ \\
\hline Indonesia & Fdi & 0.03 & 0.06 \\
& Open & -2.30 & $-3.10^{* *}$ \\
& Capfor & 1.13 & $7.89^{* *}$ \\
\hline Thailand & Fdi & 0.14 & 0.51 \\
& Open & 4.63 & 0.68 \\
& Capfor & 0.78 & $10.46^{* *}$ \\
\hline Philippines & Fdi & -0.23 & -0.51 \\
& Open & -3.78 & -0.59 \\
& Capfor & 1.29 & $4.39^{* *}$ \\
\hline
\end{tabular}

\section{Conclusion}

In this study, three variables were employed to determine their relationship to economic growth. Using panel estimation in fixed effects model, the result confirms that all variables play a role as determinant of economic growth in the ASEAN-4 countries. Governments play important roles in promoting economic growth since they have the power to shape policies. Governments in the ASEAN-4 countries should create policies that encourage FDI, openness and gross fixed capital formation. For example, the government can reduce tax on imports of goods and services within the ASEAN-4 countries. This move will reduce the prices of imports; thus will help in increasing trade openness between these countries. Agbetsiafa (2010) in a study of causality evidence between regional integration, trade openness and economic growth proposed that an increase in the number of exports in intermediate goods will improve facilities and human capital, subsequently leading to higher per capita real GDP and avoid deficits in the country.

FDI plays the most important role in determining growth as indicated by the fixed effect model in panel estimation. Via FDI, advanced technologies can be absorbed by the ASEAN-4 countries. These technologies can lead to product innovations in the countries. In order to achieve this, the governments in these countries have to assure economic, social, and political stability in the countries. These three aspects can attract foreign investors to invest in the domestic economy. The resulting increase in FDI will spur economic growth. Besides FDI and openness, gross fixed capital formation cannot be excluded in determining growth. Investment in the domestic countries will add to gross fixed capital formation and lead to more growth in the economy. Azam (2010) in a study about the impact of export and FDI on economic growth in South Asia, suggests that the governments of South Asia countries should increase total FDI inflows into the countries.

However, in the OLS estimation, only gross fixed capital formation plays a role as determinant of economic growth for each ASEAN-4 country. High saving rates may lead to higher gross fixed capital formation. The governments in the ASEAN-4 countries have to design and implement policies that can improve saving rates so that gross fixed capital formation will be enlarged.

\section{References}

Adhikary, B. K. (2011). FDI, trade openness, capital formation, and economic growth in Bangladesh: A lingkage analysis. International Journal of Economics And Finance, 6(1). Retrieved from www.ccsenet.org/ijbm

Agbetsiafa, D. K. (2010). Regional integration, trade openness, and economic growth: Causality evidence from UEMOA countries. International Business and Economics Research Journal, 9(10).

Aizenman, J., \& Noy, I. (2009). Endogenous financial and trade openness. Review of Development Economics, 13(2), 175-189. http://dx.doi.org/10.1111/j.1467-9361.2008.00488.x

Andraz, J. M., \& Rodrigues, P. M. M. (2009). What causes economic growth in Portugal: Export or inward FDI?. Journal of Economics Studies, 37(3), 267-286. http://dx.doi.org/10.1108/01443581011061276

Artis, M. J. (1984). Macroeconomics. Walton Street: Oxford University Press.

Asid, R. (2010). Economic growth analyses under the TRIPS transitions: Evidence from selected cross-country samples. International Journal of Economics and Finance, 2(3).

Azam, M. (2010). An empirical analysis of the impacts of exports and foreign direct investment on economic 
growth in South Asia. Interdisciplinary Journal of Contemporary Research in Business, 2(7).

Baltagi, B. H. (1995). Econometric Analysis of Panel Data. London: John Wiley \& Sons Ltd.

Chamhuri, S., Surtahman, K. H., \& Norshamliza, C. (2005). Ekonomi Malaysia. Petaling Jaya: Pearson Longman.

Chen, B., \& Feng, Y. (2000) Determinants of economic growth in China: Private enterprise, education, and Openness. China Economic Review, 11, 1-15. http://dx.doi.org/10.1016/S1043-951X(99)00014-0

Chimobi, O. P. (2010). The causal relationship among financial development, trade openness and economic growth in Nigeria. International Journal of Economics And Finance, 2(2).

Ekanayake, E. M., \& Sussan, A. P. (2010). The role of U.S trade with North African Nations and its impact on economic growth. Competition Forum, 8(2).

Fuller N. (1991). Principle of Economics. Tudor Publishing.

Gill, I., Kharas, H., Bhattasali, D., Brahmbhatt, M., Datt, G., Haddad, M. Mountfield, E., Tatacu, R., \& Vostroknutova, E. (2007). An East Asian Renaissance Ideas of Economic Growth. Washington: The World Bank.

Gray, M. (2002). Foreign direct investment and recovery in Indonesia: Recent events and their impact. IPA Backgrounder, 14(2).

Gujarati, D. N. (2006). Essentials of Econometrics. ( ${ }^{\text {rd }}$ Ed.). Singapore: McGraw Hill Companies, Inc.

Harris, D., Harvey, D. I., Leybourne, S. J., \& Sakkas, N. D. (2008). Local asymptotic power of the Im-Pesaran-Shin panel unit root test and the impact of initial observations. Granger Centre Discussion Paper, No. 08/02.

Hassan, Asan Ali Golam. (2004). Growth, Structural Change and Regional Inequity in Malaysia. England: Ashgate Publishing Limited.

Hermes, N., \& Lensink, R. (2003). Foreign direct investment, financial development and economic growth. Journal of Development Studies, 38.

Hoang, T. T., Wiboonchutikula, P., \& Tubtimtong, B. (2010). Does foreign direct investment promote economic growth in Vietnam?. ASEAN Economic Bulletin, 27(3), 295-311. http://dx.doi.org/10.1355/ae27-3d

Hu, Z. F., \& Khan, M. S. (1997). Why is China growing so fast? IMF Staff Papers, 44 (1).

Karlsson, S., \& Lothgren, M. (2000). On the power and interpretation of panel unit root tests. Economic Letters, 66, 249-255. http://dx.doi.org/10.1016/S0165-1765(99)00237-2

Leitao, N. C. (2010). Foreign direct investment: The Canadian experience. International Journal of Economics and Finance, 2(4).

Maddala, G. S. (1994). Econometric Methods and Application. England: Edward Elgar Publishing Limited.

Mandilaras, A., \& Popper, H. (2009). Capital flows, capitalization, and openness in emerging East Asian $\begin{array}{lllll}\text { economies. Review of International } & \text { Economics, } & 17(4), & \text { 734-750. }\end{array}$ http://dx.doi.org/10.1111/j.1467-9396.2009.00843.x

Pernia, E. M., \& Quising, P. F. (2003). Economic openness and regional development in the Philippines. ERD Working Paper, No.34.

Peterson, W. C. (1978). Income, Employment, and Economic Growth. (4 ${ }^{\text {th }}$ Ed.). Toronto: George J. McLeod Limited.

Ramasamy, B. (2008). Foreign direct investment under uncertainty: Lessons for Malaysia. Journal of the Asia Pacific Economy, 8.

Seetanah, B., Ramessur, S. T., \& Rojid, S. (2008). Financial development and economic growth: New evidence from a sample of island economies. Journal of Economics Studies, 36(2), 124-134. http://dx.doi.org/10.1108/01443580910955033

Shabri, A. M., \& Said, M. (2010). Re-examining the finance-growth nexus in Malaysia and Indonesia. The IUP Journal of Applied Finance, 16(5).

Thangavelu, S. M., \& Owyong, D. T. (2003). The impact of export growth and scale economies on productivity in Singapore's manufacturing industries. Journal of Economics Studies, 30(6), 623-535. 
http://dx.doi.org/10.1108/01443580310504471

Verbeek, M. (2008). A Guide to Modern Econometrics. ( ${ }^{\text {rd }}$ Ed.). England: John Wiley \& Sons Ltd.

Vidyattama Y. (2007). The determinants of provincial growth in Indonesia during 1983-2003. Retrieved from http://www.degit.ifw-kiel.de/papers/degit_12/C012_044.pdf

Wahid, A. N. M., Sawkut, R. \& Seetanah, B. (2009). Determinant of foreign direct investments (FDI): Lessons from the African economies. Journal of Applied Business and Economics, 9(1).

Weil, D. V. (2005). Economic growth, (1 $1^{\text {st }}$ ed.). United States of America: Addison-Wilsey.

Yu, Q. (1998). Capital investment, international trade and economic growth in China: evidence in the 1980-90s. China Economic Review, 9(1). http://dx.doi.org/10.1016/S1043-951X(99)80005-4 